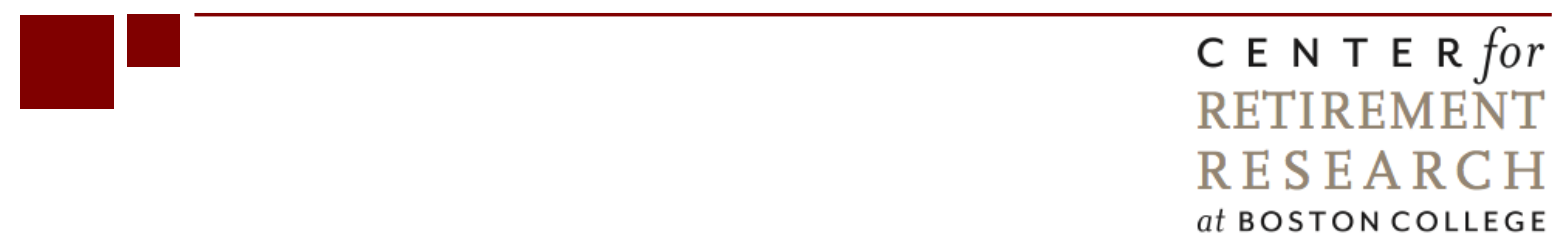

\title{
HOW DOES THE PERSONAL INCOME TAX AFFECT THE PROGRESSIVITY OF OASI BENEFITS?
}

\author{
Norma B. Coe, Zhenya Karamcheva, Richard Kopcke, Alicia H. Munnell
}

CRR WP 2011-21

Date Released: November 2011

Date Submitted: October 2011

\author{
Center for Retirement Research at Boston College \\ Hovey House \\ 140 Commonwealth Avenue \\ Chestnut Hill, MA 02467
}

Tel: 617-552-1762 Fax: 617-552-0191

http://crr.bc.edu

Norma B. Coe is associate director for research at the Center for Retirement Research at Boston College (CRR). Zhenya Karamcheva is a research associate and Richard W. Kopcke is a senior economist at the CRR. Alicia H. Munnell is the director of the CRR and the Peter F. Drucker Professor of Management Sciences at Boston College's Carroll School of Management. The research reported here was performed pursuant to a grant from the U.S. Social Security Administration (SSA) funded as part of the Retirement Research Consortium (RRC). The opinions and conclusion expressed are solely those of the author and do not represent the opinions or policy of SSA, any agency of the federal government, the RRC, or Boston College.

(C) 2011, Norma B. Coe, Zhenya Karamcheva, Richard Kopcke, Alicia H. Munnell. All rights reserved. Short sections of text, not to exceed two paragraphs, may be quoted without explicit permission provided that full credit, including (C) notice, is given to the source. 


\title{
About the Center for Retirement Research
}

The Center for Retirement Research at Boston College, part of a consortium that includes parallel centers at the University of Michigan and the National Bureau of Economic Research, was established in 1998 through a grant from the Social Security Administration. The Center's mission is to produce first-class research and forge a strong link between the academic community and decision-makers in the public and private sectors around an issue of critical importance to the nation's future. To achieve this mission, the Center sponsors a wide variety of research projects, transmits new findings to a broad audience, trains new scholars, and broadens access to valuable data sources.

\author{
Center for Retirement Research at Boston College \\ Hovey House \\ 140 Commonwealth Avenue \\ Chestnut Hill, MA 02467 \\ phone: 617-552-1762 fax: 617-552-0191 \\ e-mail: crr@bc.edu \\ crr.bc.edu
}

\section{Affiliated Institutions:}

The Brookings Institution

Massachusetts Institute of Technology

Syracuse University

Urban Institute 


\begin{abstract}
This study calculates the impact of federal income taxes on the progressivity of the Old Age and Survivors Insurance (OASI) program. It uses the Health and Retirement Study (HRS) data linked with the Social Security Earnings Records to estimate OASI contributions and benefits for individuals and households, before and after income taxes, for three birth cohorts. It uses two measures of progressivity: redistribution by decile (the difference between the share of total benefits received and the share of total taxes paid) and "effective progression" (the change in the Gini coefficient). Under both measures, the results without the income tax confirm previous findings: Social Security is progressive on an individual basis, but that progressivity is dramatically cut when one calculates it on a household basis. Adding income taxes could make the program either more or less progressive. On the one hand, the tax treatment of contributions makes the system even less progressive than generally reported. On the other hand, the taxation of benefits makes it more progressive. The net result is that adding the personal income tax to the analysis has only a small impact on Social Security's progressivity, as large effects of the specific provisions mainly offset one another. Net tax effects do, however, appear to add to progressivity over time due to the increasing percentage of households subject to taxation on their benefits. With no changes in tax laws, this trend toward greater progressivity is likely to continue.
\end{abstract}




\section{Introduction}

The Old Age and Survivors Insurance (OASI) program is designed to be progressive. Taxes are a flat percentage of a worker's earnings up to maximum taxable earnings, but the progressive benefit formula replaces a smaller share of pre-retirement earnings as earnings increase. The goal is to produce an outcome in which the ratio of benefits received to payroll taxes paid is lower for high-income individuals.

Yet, in practice, the OASI program has been much less progressive than intended. One issue is that people with higher incomes tend to live longer, which can increase the value of their benefits relative to those with low incomes, albeit by a small amount (Harris and Sabelhaus 2005). Much more importantly, while the program redistributes income from workers with higher incomes to those with lower incomes, most of it goes from men to women, who are often married to high-earning men, and the amount of redistribution is halved when calculated at the household level (Gustman and Steinmeier 2001). In addition, analysts who use an increasingly comprehensive definition of family income, ultimately including home production, find that OASI benefits might have little effect on the distribution of income (Brown, Coronado, and Fullerton 2009).

This study calculates the impact of federal income taxes on the progressivity of the OASI program, a factor currently omitted from the literature. Workers pay direct OASI contributions equal to 5.3 percent of their covered earnings. ${ }^{1}$ Because these contributions are not exempt from taxes, each dollar of contribution costs one dollar of disposable income. Employers also pay contributions equal to 5.3 percent of covered earnings. The employers' contributions are essentially payments made on behalf of workers out of workers' pre-tax income (Hammermesh and Rees 1993; Piketty and Saez 2007). This "tax deduction" for employer contributions tends to benefit high-income workers the most.

At the same time, a portion of Social Security benefits has been subject to income taxation since 1984, and this portion rises for households with greater retirement income. The strong progressivity of the income taxation of benefits makes benefits after income taxes even more progressive than the formula for benefits alone suggests. This interaction between income taxes and the OASI program has been examined in studies of typical families, but not in the context of actual workers' experiences (Goodman and Liebman 2008).

The paper proceeds as follows. Section 2 describes the conceptual framework. Section 3 presents a brief overview of prior studies. Section 4 discusses the sample and the construction of the data. Section 5 presents the results for the extent of redistribution for single individuals and for couples without the personal income tax. Section 6 discusses how including the personal income tax provisions changes these results. Section 7 extends the analysis to later cohorts in the HRS that reflect the increased labor force participation of women and the greater taxation of benefits in retirement. Section 8 concludes that the effect of taxation, while a net zero effect on redistribution measures for previous cohorts, becomes increasingly important in measuring the redistribution of Social Security for current and future cohorts.

\footnotetext{
${ }^{1}$ The total taxation for OASI and Disability Insurance (DI) programs is 6.2 percent of wages. We are following the literature and examining OASI separately, and thus only take into account the 5.3 percent portion.
} 


\section{Conceptual Framework}

This section describes how Social Security's benefit structure could redistribute between those with high and low incomes; how the federal income tax could affect that redistribution; and how the assessment of the progressivity of Social Security depends on how the question is framed.

\section{Social Security’s benefit structure. Since 1939, Social Security's simple wage} replacement role has been supplemented by adequacy considerations, through a minimum benefit (at one time), dependents benefits, and a progressive benefit formula. It is a unique system in which the contributions are determined on an individual level, but the benefits are calculated on a household level. Thus, Social Security could redistribute income by providing relatively higher benefits to low-income workers or by providing benefits to spouses or to widow(ers) who might be low-income individuals.

The current benefit calculation is a three step process. First, a worker's previous earnings are restated in terms of today's wages by indexing past earnings to wage growth. Second, earnings for the highest 35 years are then averaged and divided by 12 to calculate Average Indexed Monthly Earnings (AIME). Finally, the Primary Insurance Amount (PIA) is the sum of three separate percentages that are applied to portions of the AIME (SSA 2011a). The bendpoints are indexed for wage growth, and thus depend on the year in which a person reaches age 62. Specifically, for workers first becoming eligible for benefits in 2011, their PIA is the sum of:

- 90 percent of the worker's first $\$ 749$ of AIME, plus

- 32 percent of AIME between $\$ 749$ and $\$ 4,517$, plus

- 15 percent of any AIME in excess of $\$ 4,517$.

This PIA is continually recalculated as long as the individual remains employed; it is indexed to prices from age 62 . The benefit actually paid depends on when the worker claims. Actuarially reduced benefits are available at age 62, and benefits are actuarially increased between the normal retirement age and age 70 .

In addition to the worker's benefit, Social Security provides dependents' benefits. These benefits are designed to support the lower earner in a couple, so, while they are not gender based, they typically go to women. Thus, a wife is entitled to two types of benefits: 1) a spouse's benefit that will top-up her own retirement benefit up to 50 percent of her husband's PIA — the benefit unreduced for early retirement; and 2) a survivor's benefit that will top-up her own benefit to 100 percent of her husband's actual benefit (which reflects any actuarial reductions for early claiming).

In short, Social Security is designed to provide additional support to low paid workers and to people who have little or no earnings throughout their life.

The federal income tax and Social Security. The first way in which the personal income tax impacts the progressivity of OASI is on the contribution side. Workers and their employers 
each pay an OASI tax of 5.3 percent of covered earnings. In 2011, covered earnings are $\$ 106,800$. Workers' contributions are not exempt from the personal income tax, so each dollar of contribution costs one dollar of disposable income. In contrast, the employer's contribution, made on behalf of the worker, is not subject to personal income taxation. For workers who pay no income taxes, each dollar of employer contribution effectively costs one dollar of disposable income. For workers who pay income taxes, the effective cost falls from 90 cents of disposable income for those with low taxable incomes to 65 cents or less for those in the highest federal income tax brackets, assuming full incidence of the tax (Hammermesh and Rees 1993; Piketty and Saez 2007). Therefore, the interaction between income taxes and OASI contributions makes Social Security more regressive.

The degree to which the income tax makes Social Security contributions regressive, and where in the income distribution the effect starts, depends on how one treats the Earned Income Tax Credit (EITC). ${ }^{2}$ The EITC comprises a series of credits that operate differently for different types of families. All share a common formula, however. The formula increases the refundable credit for each dollar of earnings up to a certain level; maintains the maximum credit through an amount of additional earnings; and then gradually phases out the credit at higher incomes.

Figure 2 illustrates the structure and level of the EITC in 2011. A worker with three children could claim a maximum credit of $\$ 5,751$, with the credit phased out at $\$ 43,998$. Thus, over a considerable range, low-income households could be viewed as facing a negative tax. The effective marginal tax rates in 2011 are illustrated in Figure 3. Using this negative rate will make employer contributions appear more burdensome than if their marginal rate were simply viewed as zero.

The second, and most straightforward, effect of the personal income tax on the progressivity of Social Security is the taxation of benefits. Under current law, individuals with less than $\$ 25,000$ and married couples with less than $\$ 32,000$ of "combined income" do not have to pay taxes on their Social Security benefits. (Combined income is adjusted gross income as reported on tax forms plus non-taxable interest income plus one half of Social Security benefits.) Above those thresholds, recipients must pay taxes on either 50 percent or 85 percent of their benefits. When this provision, first introduced as part of the 1983 Social Security legislation, became effective only a fraction of households who received Social Security had to pay taxes on their benefits. But the thresholds are not indexed for wage growth or even for inflation, so over time a significantly higher percentage of recipients have become subject to tax. Now, about onethird of Social Security beneficiaries pay income taxes on their benefits (Hinden 2011). In 2010, $\$ 22$ billion of revenue was raised from the benefit tax, almost eight times the revenue raised in 1984. Figure 1 illustrates the growth in the tax revenue. The taxation of benefits makes Social Security more progressive.

\footnotetext{
${ }^{2}$ This provision, which was originally introduced in 1975, began as a modest attempt to reduce the regressive effects of a rising payroll tax (Holt 2006). The credit was made permanent and expanded significantly in 1986. It was expanded again in 1990, and in 1993, President Clinton and Congress doubled its size to ensure that full-time minimum wage workers would not live in poverty.
} 
Framing issues. As described below, a number of studies have looked at the extent to which Social Security redistributes from those with high lifetime income to those with low. All of those researchers had to make decisions regarding a number of issues.

Social Security. Social Security consists of both a retirement (OASI) and a disability insurance program (DI). Focusing just on the retirement portion will understate the amount of redistribution in the entire program because the bulk of disability insurance benefits go to lowincome individuals. We follow the pattern of earlier studies and examine only the OASI program.

Unit of analysis. The results will differ substantially depending on whether single individuals or couples are the unit of analysis. The reason is that the spouse's benefit often goes to individuals who look like low-wage workers but are actually the spouses of high earners. We examine redistribution at both the individual and the household level.

Cohort selected. A major offset to Social Security's progressive benefit formula is the payment of the spouse's and survivor benefits to the wives of high-earning men. To the extent that the labor force activity of women increases, these payments become less important and the system will look more redistributive. Moreover, an increasingly large percentage of households will be required to pay taxes on their benefits. We first examine the cohort born between 1931 and 1941 and then expand the analysis to include the War Baby (1942-1947) and the Early Baby Boomer (1948-1953) cohorts.

Definition of income. Deciding on the appropriate income definition can affect the results. Among the alternatives discussed in the literature are: average indexed monthly earnings of the individual, average indexed monthly earnings of the higher earner in the household, potential earnings, total covered earnings of both spouses. Generally the broader the income concept employed, the less redistribution. We stick to measuring redistribution based on actual earnings.

Measures of progressivity: Progressivity can be measured in a number of ways. We report two different measures so our work can be easily compared to the previous literature. The redistribution by decile is the difference between the proportion of benefits received and the proportion of contributions made by respondents in each AIME decile. Effective progression compares the Gini coefficient before and after Social Security. Each measure will give a somewhat different answer regarding the progressivity of Social Security.

\section{Literature to Date}

Questioning whether Social Security achieves its redistributive goal has a long history. Milton Friedman (1972) and Henry Aaron (1982) identified factors that could offset the redistribution in the benefit formula. People who enter the labor force later — presumably those with more years of education and therefore higher incomes - might contribute for only the 35 
years required for the benefit calculation, while those with long careers would contribute for more years with little impact on their benefits. Similarly, higher income people tend to live longer, and since Social Security is paid as an annuity, longer life expectancy would increase the relative payout to high-income workers. Differential mortality, interestingly, has not turned out to be that important a factor in the measured redistribution (Harris and Sabelhaus 2005).

What does turn out to be important is whether redistribution is measured on an individual or a household basis and whether earnings are measured as actual or "potential." Using broad measures of household income, three early papers take different approaches but come to a similar conclusion: Social Security is not very effective at redistributing income among families.

Gustman and Steinmeier (2001) use the first wave of the HRS, which focuses on the cohort born 1931-1941. ${ }^{3}$ They first measure redistribution by comparing lifetime taxes and benefits across individuals arrayed by AIME deciles and find significant redistribution from high to low earners, much of this from men to women. They then add the benefits and taxes for both spouses to look at family units and find that the extent of redistribution is roughly halved. Finally, they array families by earnings in years that they work to get a measure of potential earnings, and find that the benefit formula redistributes from families with high potential earnings to those with low potential earnings.

Liebman (2002) uses a microsimulation model based on the earnings history and retirement dates of the 1925-1929 birth cohorts from the Survey of Income and Program Participation (SIPP) to calculate the internal rate of return, net transfer, and lifetime tax rates for the members (assuming that they had lived under current Social Security rules for their entire lifetimes). He finds that the program transfers income from people with low life expectancies to those with high life expectancies, from singles to couples, from two-earner couples to one-earner couples, and from those with more than 35 years of work to those with less. But income-related transfers are only 5 percent to 9 percent of benefits paid, because the effect of the progressive benefit formula is largely offset through the payment of the spouse's benefit to high-income households and the longer longevity of high-income households. His results are sensitive to the discount rate; a higher rate produces more redistribution by some measures and less by others.

Coronado, Fullerton and Glass (2000) use the Panel Study of Income Dynamics (PSID) with family earnings projected into the future to measure the program's impact on inequality by the Gini coefficient with and without Social Security transfers. They gradually broaden the definition of income from individual lifetime earnings to pooled resources within a household to potential income, where each family member works 4,000 hours. They find that the current OASI program is only slightly progressive, with progressivity declining as the definition of income is broadened.

Brown, Coronado, and Fullerton (2009) look more narrowly at redistribution toward the poor and at changes in progressivity over time, using data from the PSID (1968-1993). Again the finding is that the more comprehensive the concept of income, Social Security has less of an effect on inequality. Using the most comprehensive measure - potential earnings at the

\footnotetext{
${ }^{3}$ Gustman, Steinmeier and Tabatabai (2011) are simultaneously working on expanding Gustman and Steinmeier (2001) analysis to the Early Baby Boomer cohort. We have only seen a preliminary version of the paper, thus refrain from discussing it here.
} 
household level - Social Security has virtually no overall impact on Gini coefficients. This result, however, is driven largely by the lack of redistribution between middle and higher parts of the income distribution, and those in the bottom quintile do receive net benefits from the program. Moreover, the system is more redistributive for baby boomers than for pre-boomers.

The conclusion that Social Security is becoming more redistributive over time also emerged from two other studies. Cohen, Steuerle and Caruso (2001) use the Modeling Income in the Near Term (MINT) model, a micro-simulation model based on the 1990-93 SIPP Survey matched with Social Security earnings records, to study the extent of redistribution in Social Security by education, race, and income and find that the system becomes more progressive over four generations. Smith, Toder and Iams (2001) also use the MINT model to study the impact of the OASI program on inequality. They find that the redistributive effects of Social Security are changing over time, partly because of changes in tax rates and benefits, but more importantly because of changing demographics and earnings patterns in the work force.

The following analysis, building on the existing literature, has two goals. The first is to investigate how incorporating personal income taxes affects Social Security's progressivity for both individuals and households. The second goal is to see how progressivity changes over time as more women work and more households are subject to taxation on their benefits.

\section{Sample and Data Construction}

Determining the impact of the federal income tax on Social Security progressivity is a four-step process. The first step is to create a data set that includes, for a nationally representative sample of individuals, the stream of income over their lifetimes, OASI taxes paid, and OASI benefits received. The second step is to produce different measures of redistribution without the interaction with the personal income tax. The third step is to add the income tax and reassess the extent of redistribution. The fourth step updates the results for subsequent cohorts of the HRS. This section discusses step one - constructing the relevant data set. The strategy is to build on Gustman and Steinmeier (2001) so that the base case - no personal income tax — is consistent with the existing literature.

The sample. The Health and Retirement Study (HRS) is a nationally representative study of older Americans. The survey began in 1992 with an initial cohort of 12,652 individuals from 7,607 households in which at least one member was born from 1931 to 1941 . Additional cohorts were added later; the War Baby cohort (WB, born 1942-1947) was added in 1998; the Early Baby Boomer (EBB, born 1948-1953) in 2004. Individuals may opt to have their Social Security earnings histories linked to their survey; approximately 70 percent of respondents have done so.

Lifetime earnings. The administrative data provides Social Security earnings histories back to 1951 for the approximately 70 percent of the sample that has given permission to link. Previous work suggests that giving permission to link is essentially random (Kapteyn et al. 2006). Thus we follow Gustman and Steinmeier (2001) and estimate earnings histories based on 
survey data on previous jobs and wages, using the estimated returns to tenure from Anderson et al. (1999).

To measure progressivity, it is necessary to project earnings beyond the year at which the individual last gave permission to match to the administrative data. Again, we follow Gustman and Steinmeier (2001). For individuals with self-reported earnings, the assumption is that their real earnings observed in the last reported year persist until their expected retirement date. For those without self-reported earnings, zeros are projected for future years. All respondents are assumed to claim Social Security benefits at their self-reported expected retirement age. If the expected retirement age was greater than 70 , or if the individual indicated that he never expected to retire, a retirement age of 70 was used unless the individual had already worked beyond that age. If the respondent did not provide an expected retirement age, we assign them a claiming age so that the age distribution of claiming matches the Social Security reported claiming ages (Table 6.B5.1, 2010c). We also use this self-reported retirement age to determine the year in which financial wealth drawdown begins.

Social Security taxes. Combining the actual earnings with the simulated earnings yields a complete earnings profile for each individual in the sample from 1951 to retirement age. This earnings profile then serves as a base for calculating OASI taxes paid, based on the schedules in place at the time the wages were earned. Even though the employee and the employer each pay half the tax, theory and research (Hamermesh and Rees 1993, Piketty and Saez 2007) suggest that the worker bears the full burden. Since the Social Security earnings histories are capped at the taxable maximum, the calculation involves simply applying the combined rate to earnings, and capping any self-reported or imputed earnings data.

Social Security benefits. As discussed in Section 2 of this paper, the Social Security PIA is calculated by applying a non-linear formula to each worker's AIME. In computing the AIME, earnings prior to age 60 are indexed by the average wage index for the year the individual attains age 60. Earnings after age 60 are not indexed. AIME is the simple monthly average of the indexed earnings in the 35 highest-earnings years.

A retiree is entitled to a benefit equal to the PIA at the FRA (which was 65 for the first cohort under consideration, 66 for the last cohort). A worker may choose to retire as early as age 62 , with reduced benefits. In contrast, if a worker elects to delay receipt of benefits to an age as late as 70 , the eventual benefits are permanently increased for each year of delay.

In addition to retirement benefits for covered workers, OASI provides certain benefits to the spouse and other dependents of retired or deceased workers. The spouse of a retired worker can receive the greater of the benefit based on his or her own earnings or one-half of the PIA of the retired worker (designated as the "spousal benefit"). Once spousal benefits have begun, costof-living adjustments are handled in the same manner as are the worker's benefit. The spouse of a deceased worker can receive a survivor's benefit equal to the higher of the benefit based on his or her own earnings, or 100 percent of the benefit to which that worker was entitled.

Marital status at the age of retirement and marital history are important when determining what spousal or survivor benefits an individual is eligible to receive. For those not yet retired, 
we assume the last reported marital status does not change before retirement. For those with a previous marriage that lasted 10 or more years, they are entitled to spousal benefits from an exspouse for whom we do not have any information. To address this issue, we match the respondent to someone else in the survey by gender, education, race, and 5-year birth year band. We then use the earnings histories of the spouse of the matched individual to compute the spousal and survivor benefit available from the ex-spouse.

Thus, each individual's observed and projected earnings and marital histories are used to compute the AIME, the PIA, the spouse's benefit, and the survivor benefit. We assume all individuals start claiming OASI benefits at their self-reported expected retirement age.

Mortality and discount rate assumptions. Virtually all progressivity measures require transforming tax and benefit streams into present discounted values. That transformation requires assumptions about mortality probabilities and discount rates.

The mortality assumptions imbedded in these calculations start with mortality tables from the SSA, which have data by age and gender. These tables are then adjusted, based on the results of Brown, Liebman and Pollet (2002), to reflect the fact that survival probabilities vary with education and race. This adjustment will work against the progressivity in the benefit formula, but, as reported earlier, its impact is relatively small (Harris and Sabelhaus 2005).

For the discount rate, we use the 10-year U.S. government bond rate prior to 2010 and the SSA (2011b)'s intermediate interest rate projection after 2010.

The picture by cohort. Tabulating the data for the HRS cohort reveals several reasons why demographic factors offset the progressivity in the benefit formula. ${ }^{4}$ First, as evident in Table 1, which presents average quarters of work and household AIME by individual AIME deciles and gender, men and women are not equally spread through the individual AIME deciles. Over half of the men are in the top three AIME deciles for the HRS cohort while three quarters of women fall in the bottom half of the AIME distribution. The reason women are in these low categories is that they have few years of work. Second, the lifetime household income for these women is much higher than that for low AIME men, suggesting that these women are spouses of high-earning husbands.

Moving from the HRS cohort to the WB cohort (Panel B) and EBB cohort (Panel C), the data clearly show the increased labor force participation among women and an increase in assortative mating. Fewer women are in the lower individual AIME deciles, and the average number of quarters worked by women increases by cohort for every decile. In addition, the average household AIME decreases for low-earning wives, suggesting that low-earning women are more likely to be married to low-earning men than in the previous cohorts.

\section{Extent of Redistribution without Personal Income Tax}

\footnotetext{
${ }^{4}$ Following Gustman and Steinmeier (2001), annual and lifetime earnings in Table1are indexed to 1992 using Social Security's annual wage index. Table 1, however, does not focus on "significant" earnings but rather reports all earnings.
} 
Armed with earnings histories, tax payments, projected benefits, and a discount rate, it is possible to examine the extent to which Social Security redistributes income from the high income to the low income. This study uses two of the many possible measures of progressivity: 1) net redistribution of benefits by decile, and 2) effective progression: the Gini coefficient postversus pre-Social Security (Brown, Coronado, Fullerton (2009).

Table 2 presents the first measure of redistribution for the HRS cohort in three different ways. Panel A presents the individual-level analysis, using only the Social Security taxes and benefits that respondents will collect based on their own earnings. Panel B includes spousal and survivor benefits but compares them to individual taxes and uses only an individual's earnings to determine the AIME decile. Panel $\mathrm{C}$ is the full household-level redistribution analysis, using the sum of each spouse's AIME to determine earnings deciles, and including all benefits (own, spousal, survivor) when determining the benefits received.

Rows 1-3 of each panel of Table 2 report the taxes paid, the benefits received, and the net redistribution by AIME decile, defined as the share of benefits received less the share of total taxes paid. For example, Panel A shows that individuals in the highest decile paid $\$ 187,000$ in taxes, or 23 percent of taxes $(187 /(82 * 10))$ and received $\$ 124,000$ in benefits, or 17 percent of the benefits $(124 /(73 * 10))$, for a net value of -5.95 percent. Due to the prevalence of women who work insufficiently long to earn their own worker benefits, the net redistribution to the lowest decile is also negative. Deciles 2-6 get net positive benefits from Social Security, meaning that as a decile they get more than they contribute to the system. At the individual level, the third decile has the highest net benefits, getting over 3 percent. The final column indicates the fraction of total benefits that are redistributed among the deciles. Almost 12 percent of the program is redistributed among the deciles.

Once household benefits are taken into account, the program appears much more redistributive, with 20 percent overall being redistributed among the deciles (Panel B). It becomes clear why by examining the difference in the benefits received when counting worker benefits only (Panel A) and household benefits (Panel B). The lowest decile increases its benefits by $\$ 53,000$, while the highest decile does not get any additional benefits paid. However, the full household-level analysis (Panel C) cuts the redistribution to less than 7 percent overall. The results confirm what intuition and previous research have indicated. A meaningful amount of redistribution occurs between high-income and low-income individuals, but about half of that disappears when the analysis is done on a family basis. Since a lot of the individual redistribution is to non-working wives of higher-paid workers, the family is the better basis for assessing the redistributive effects of Social Security.

The second measure of redistribution is effective progression, which is defined as:

\footnotetext{
5 The U.S. GAO (2004) reviews concepts and measures of redistribution and estimates in the literature, including calculations that compare low and high income groups with respect to: the share of total benefits received, the benefit/tax ratio, the internal rate of return, and the benefit/earnings replacement rate. Future versions of this paper will include the benefit/tax ratio. We do not compare the progressivity of different income streams by comparing their internal rates of return (IRR), because we cannot rank the values of different income streams according to the magnitudes of their IRRs (Brigham and Houston 2007). The formula for calculating the IRR assumes that households are able to shift earnings across years by borrowing or investing at the calculated IRR. Accordingly, the IRR formula values different income streams according to different opportunity costs of funds. Taking the actual opportunity cost of funds into account not only alters the relative values of income streams, it also can alter the ranking of the value of the streams
} 
$E P=\frac{1-\operatorname{Gini}_{A T}}{1-\operatorname{Gini}_{B T}}$

where Gini $_{\mathrm{BT}}$ and Gini $_{\mathrm{AT}}$ are the before-tax and after-tax values of the Gini coefficient. This concept, which is derived from the public finance literature, is designed to measure how the imposition of a tax changes the distribution of income (Musgrave and Thin 1948; Kiefer 1984). The Gini coefficient, which measures the inequality of a distribution, is the ratio of the area between the 45-degree line in a graph and a curve that measures the cumulative percentage of individuals against the cumulative percentage of income earned by those individuals. If all individuals have equal income, the Gini would be zero. Higher values of the Gini indicate higher degrees of inequality. A Gini equal to one would imply that one person had all the income.

In the case of evaluating the progressivity of Social Security, the "tax" for each individual is the lifetime net tax from Social Security — that is, the present value of OASI tax payments minus the present value of OASI benefits. The measure of effective progression simply compares the degree of inequality after accounting for the OASI program to the degree of inequality before Social Security, holding pre-tax earnings fixed. A value of one indicates that Social Security has no impact on the distribution of income; a value greater than one indicates a progressive system, while a value of less than one indicates regressivity. The results are presented in Table 3. The calculation shows that the overall system is progressive at the individual level. One question is how to interpret 1.01. Brown Coronado, and Fullerton (2009) provide some benchmarks. Using a broad measure of annual income, Lerman and Yitzhaki (1995) calculate a Gini coefficient of 0.67 before taxes and transfers, and 0.58 afterwards. The corresponding effective progression measure is 1.16 for the entire tax and transfer system. Looking only at annual individual income taxes and annual income, Keifer (1984) finds that the Gini falls from about 0.47 to 0.44 (effective progression $=1.06$ ). This figure would be smaller on a lifetime basis. Since the lifetime measure for Social Security alone is EP=1.01, it does appear that Social Security helps redistribute from rich to poor. The effect at the household level is again cut almost in half, with the effective progressivity measure dropping to 1.007 .

\section{Redistribution Including the Personal Income Tax}

Researchers looking at the distributional effects of Social Security have ignored the many ways in which the personal income tax interacts with Social Security taxes and benefits. The rationale is generally threefold: 1) to provide consistency with earlier studies; 2) to avoid the large data requirements for carrying out such an exercise; and 3) to reflect the ambiguity over whether the federal income tax provisions should be considered part of the tax code or part of Social Security (Gustman and Steinmeier (2001) and Brown, Coronado, and Fullerton (2009)). The strength of the rationale for including personal income taxation in evaluating Social Security's progressivity varies with the individual provisions.

The most controversial provision is probably the income tax treatment of Social Security contributions. The exclusion of the employer's Social Security contribution from taxable income is consistent with the tax treatment accorded employer contributions to defined benefit plans and 
could arguably be considered part of the federal income tax code, making the income tax less progressive. However, with the assumption of full tax incidence on the employee of the employer's contribution, Social Security contributions are made with partly pre-tax and partly post-tax dollars, and it could also be argued that it makes sense to account for this treatment within the Social Security redistribution measures.

The EITC provision, which was originally introduced in 1975, is more intimately entwined with Social Security provisions. It actually began as a modest attempt to reduce the regressive effects of a rising payroll tax (Holt 2006). The credit was made permanent and expanded significantly in 1986. It was expanded again in 1990, and in 1993, to achieve a broader goal that full-time minimum wage workers would not live in poverty.

The third component - subjecting Social Security benefits to income taxes — should clearly be considered part of the Social Security program. The provision was introduced in 1983 as one of changes proposed by the so-called Greenspan Commission. The goal was to increase revenues for Social Security by transferring the receipts annually from the Treasury to the Trust Fund.

Because different portions of the lifetime income distribution will be affected by each of these tax provisions, we present the results adding each component separately for the HRS cohort in Table 4. The individual-level analysis is presented in Panel A, and the household-level analysis in Panel B. The baseline case is presented in the first row of each panel.

Exclusion of employer's contribution. The exclusion of the employer's contribution from taxable income reduces the effective cost of each dollar of contribution to 90 cents for those with low taxable incomes and to 65 cents or less for those in the highest federal income tax brackets in 2011. Thus, this factor unambiguously makes the system less redistributive.

To estimate the impact of the exclusion requires each household's marginal tax rate for each year of earnings. Unfortunately, OASI earnings data report earnings only up to the taxable maximum for the year. In order to be able to determine the marginal rate, earnings above the taxable maximum were imputed for sample members with reported earnings at the taxable maximum.

To do so, we estimated a Tobit regression of log of earnings on age, age squared, and education for each year between 1951 and 2007 to get mean earnings and an error term. Using these parameter estimates, we randomly drew from a normal distribution with the appropriate mean and variance until each top-coded observation was replaced with a draw above the top code. Post-2007, the predicted uncapped earnings are projected to stay constant in real terms until the respondent's retirement age.

To make the marginal tax rate calculation tractable required several simplifications. First, taxpayers were assumed to use the standard deduction. This will overestimate the tax burden on mortgage-holders above the zero-income tax bracket. ${ }^{6}$ Second, marginal tax rates were assumed to depend on earnings only. No attempt was made to include investment income, capital gains, rents or other sources. This assumption slightly understates the relief offered to

\footnotetext{
${ }^{6}$ Because any error introduced by this mis-measurement impacts both the contribution and the benefits side of the redistribution measures, our sensitivity tests suggest that this assumption will have little impact on the redistribution numbers.
} 
moderate earners with extensive non-wage income. ${ }^{7}$ Third, in the case of two-earner couples, each spouse was assumed to have the household's marginal rate. This assumption overstates relief for two-earner families, because one of the earners faced a lower rate, but it is consistent with the tax treatment of the next dollar regardless of which spouse earns it. ${ }^{8}$ We calculate the marginal federal income tax rates using the TAXSIM calculator, available from the National

Bureau of Economic Research (see Feenberg and Coutts (1993)). We assume 2013 tax code rules are constant going forward. ${ }^{9}$ Armed with the marginal rate for each individual and household, we recalculated the employer's contribution to Social Security and recalculated the present discount value of taxes paid. ${ }^{10}$

The second row of each panel in Table 4 presents the net redistribution calculations by AIME deciles including the income tax exclusion of employer contributions. As expected, this lowers the redistributiveness of the program at both the individual level (Panel A) and the household level (Panel B).

Earned Income Tax Credit. When the EITC was first enacted, it refunded more than 85 percent of the total employee-employer payroll tax. ${ }^{11}$ If the only effect of the provision were to reimburse low-wage workers for payroll tax contributions, the marginal rate would be zero and they would simply pay no tax. But, as shown in Figure 3, the EITC involves a negative tax as the payment increases with gross earnings. Simply put, for individuals in the phase-in range of the credit, every dollar earned yields them $\$ 1.40$ of take-home pay. Since we assume that the employee bears the burden of the employer's tax, every dollar in tax that the employer pays is one dollar of forgone income, and correspondingly $\$ 0.40$ less in tax refunds. In order to incorporate the EITC into the redistribution calculations, we multiply the employer contribution by the individual's (household's) effective marginal tax rate, including the negative rates. Applying negative marginal rates makes the contribution more burdensome to the employee. In addition, for individuals (households) that get a tax refund, we allow that refund to lower the amount they pay from their portion of the tax.

The third row of each panel in Table 4 presents the net redistribution calculations by AIME deciles including the EITC. As expected, this adds to the redistributiveness of the program at both the individual level (Panel A) and the household level (Panel B), but its effect is quite small.

\footnotetext{
${ }^{7}$ In future versions of this paper we will test the sensitivity of our results to the inclusion of non-wage income and itemized deductions.

${ }^{8}$ One exception to this rule that we take into account is the extra deduction for two-earner couples, which was available in the early 1980 's.

${ }^{9}$ The TAXSIM calculator provides both federal and state income tax calculations back to 1960 . Since we use restricted data, we ran the NBER's software in our restricted data facility. We do not use the state income tax rates since we do not merge the state identifiers with the detailed earnings histories. We do not take a stand on who is the "first earner" and who is the "second earner" in a household, but instead apply the household marginal rate to both individuals in a couple, thus assigning each individual the tax rate that the next dollar in the household would face regardless of who earned that dollar. We do, however, take into account the extra 10-percent deduction from taxable earnings from the lowest-paid spouse in two-earner couples that was available during the 1980's, reducing the household tax rate for the lower earner.

${ }^{10}$ For this calculation, we ignore negative rates generated by the EITC; and if a marginal tax rate is negative because of the EITC, we set the rate equal to zero.

${ }^{11}$ At the time the combined OASDI \& HI tax rate for employee and employer together was 11.7 percent, while the EITC credit rate was 10 percent. The combined OASI rate alone was 8.75 percent.
} 
The taxation of Social Security benefits. As described in the introduction, individuals with more than $\$ 25,000$ and married couples with more than $\$ 32,000$ of "combined income" have to pay taxes on either 50 percent or 85 percent their Social Security benefits. (Combined income is adjusted gross income as reported on tax forms, plus nontaxable interest income, plus one half of Social Security benefits.)

To estimate the impact of this provision requires projecting each household's "combined income" in retirement. To project a future income stream, we annuitize all financial wealth (non-housing wealth) reported at the last time we observe them in the survey and assume a constant real income stream. Any income from defined benefit pension plans or existing annuities is also included. We calculate the future income stream for households considering the likelihood of individual mortality, giving them a two-thirds joint and survivor annuity and adjusting their Social Security benefits to survivor or their own benefits. We assume that the Social Security benefit taxation threshold remains fixed in the future in nominal terms, thus declining in real terms. Net redistribution by decile and the effective progression are then recalculated using the diminished benefit stream.

The fourth row of each panel of Table 4 shows the redistribution when all of the income tax elements are included in the calculations. Taxation of benefits increases the overall progressivity by approximately 1 percent, at both the individual level (Panel A) and the household level (Panel B). While the overall picture for the HRS cohort does not change dramatically due to taxation, the pattern of redistribution by decile is impacted. At the individual level, the shape is more exaggerated, with the lowest and the top deciles paying even more into the system when taxation is included. At the household level, the net redistribution measures increase for deciles 5-9.

The impact of including the personal income tax in the analysis is reported for effective progression in Table 7. Both measures paint a similar picture. Adding taxes to the analysis makes very little difference for the HRS cohort in terms of how redistributive the program is. Table 7 indicates that the effective progression measure increases by less than 0.001 at both the individual and household levels.

\section{Change in Redistribution over Time}

This final section re-estimates the results presented above for two later cohorts in the HRS, the WB cohort (born 1942-1947) and EBB cohort (born 1948-1943). The reason for doing so is twofold. First, most of the redistribution at the individual level is from men to women, with the money often going to the non-working wives of high earners. As shown in Figure 4, the labor force participation rate for prime age (35-44) married women has increased sharply. At the risk of oversimplification, single women have always worked but married women have not. This picture began to change in the 1950s when appliances made housekeeping less time-consuming and the demand for labor was strong. The participation of married women continued to grow thereafter. The more married women work, the more they will earn their own benefits and the less redistribution will go in their direction. The HRS cohort would have women only at the beginning of this major social change; later cohorts will have a much larger percentage of married women who will have spent most of their lives in the labor force. 
The second time-sensitive phenomenon is the taxation of OASI benefits - the personal income tax provision most closely linked to Social Security. When this provision, which was introduced as part of the 1983 Social Security legislation, became effective, only a fraction of households who received Social Security had to pay taxes on their benefits. But the thresholds are not indexed for growth in average wages or even for inflation, so over time a significantly higher percentage of recipients have become subject to taxation. By 2010 households receiving the median benefit were subject to taxation, and taxation will continue to progress down the income scale. The increasing taxation of benefits makes Social Security more progressive. Table 5 presents the step-by-step progression of moving from the HRS to the WB cohort at the individual level to see what has the greatest impact on the measures of redistribution. Panel A presents the baseline case (no taxes) for those respondents born between 1936-1941 (about half of the HRS cohort). Because each cohort experiences different earnings growth, step 1 changes the average wage index to match the earnings experience of the WB cohort instead of the HRS cohort. This simple change makes the entire program more progressive by almost 1 percentage point, with the biggest impact on high earners. Mortality rates have also changed among the cohorts, and adjusting the mortality rates to reflect those facing the WB cohort (step 2) has little impact on the redistribution, confirming earlier work (Harris and Sabelhaus 2005).

The financing of Social Security has also changed over the years, with increases in the FICA tax rate and increases in the taxable maximum, impacting the taxes paid, and decreases in the FRA decreasing the benefits received. This again lowers the amount of redistribution within the program (step 3), albeit by a small amount. We then adjust the interest and discount rates to reflect the WB experience (step 4), which again lowers the amount of redistribution and is only now slightly higher than the original calculations (base case).

The last step is to use the actual work histories of the WB cohort. This decreases the overall redistribution by 2 percentage points, to 10 percent. There are fewer workers who do not collect their own benefits in the lowest decile and longer work histories yield higher benefits in the second decile. Deciles 3-6 are working a lot more (and paying more in taxes) but are not delaying their claiming age long enough to compensate, thus they experience a lower percent redistributed to those deciles, albeit still positive. Less is being redistributed away from the top four deciles.

While this explains the underlying differences in the base case between the cohorts, we want to focus on the impact of taxation. The results for the HRS, WB, and EBB cohorts are presented in Tables 6 and 7, for the net redistribution and effective progression measures respectively, at the individual and household level. A pattern emerges from both measures: while ignoring income taxes had little impact on the measures of redistribution for the HRS cohort, going forward that assumption could lead to faulty conclusions.

Table 6 shows the net redistributed by cohort, with and without taxes. While the baseline redistribution measures vary based on the cohort examined for a variety of reasons already explored, the impact of taxes grows over time, especially at the household level. Overall, the impact of taxes decreases the percent redistributed by 0.05 percentage points for the HRS cohort but increases the percent redistributed by 0.15 percentage points for the EBB cohort. 
In addition, moving from the individual-level to the household-level analysis no longer cuts the redistribution measures in half; it decreases by only one-quarter.

Table 7 illustrates the impact of taxation on the effective progression across the cohorts, at the individual and household level. Again we see a very clear picture. While the overall measure of redistribution has decreased across the cohorts, the impact of taxation increases across the cohorts. Ignoring the interaction between OASI and the personal income tax led to an underestimation of the effective progression of only 0.0002 ; this increases to 0.0012 by the EBB cohort.

Sensitivity Tests. We simplified the tax calculation by only taxing reported earnings in our calculations. For individuals with substantial deductions, namely mortgage deductions, we are overestimating the tax rate. We also assume complete annuitization of all financial wealth at retirement to calculate the taxable income stream until death. Considering the infrequency of annuitization and the frequency of inheritances, we may also be overestimating the persistence of the taxation of benefits in retirement. To address these concerns, we recalculated the progression measures assuming a 10 percent lower tax rate than calculated by TAXSIM for all individuals with a positive tax rate. Because this impacts both the contribution and the benefits side of the redistribution measures, this turns out to have very little impact on the numbers reported in Tables 6 and 7. For example, the overall median redistribution at the household level for the HRS cohort increases from 6.83 to 6.85 ; for the WB cohort it increases from 6.63 to 6.64 .

\section{Conclusion}

This study calculates the impact of federal income taxes on the progressivity of the OASI program. It uses HRS data linked with the Social Security Earnings Records to estimate OASI contributions and benefits for individuals and households, before and after income taxes. It uses two measures of progressivity - redistribution by decile (the difference between the share of total benefits received and the share of total taxes paid), and effective progression (the change in the Gini coefficient). Under both measures, the results without the income tax are exactly what others have found: Social Security is progressive on an individual basis, and about half as progressive when measured on a household basis for the HRS cohort. Adding income taxes could make the program either more or less progressive. On the one hand, the tax treatment of contributions makes the system even less progressive than generally reported. On the other hand, the taxation of benefits makes it more progressive. The net result is that adding the personal income tax to the analysis makes Social Security more progressive on both the individual- and household-level bases for the HRS cohort, but has a relatively small effect. Importantly, the impact of taxation increases across cohorts. Ignoring taxation historically has not led to much under-reporting of the redistribution of the OASI program; that is not true going forward. 


\section{References}

Aaron, Henry J. 1982. Economic Effects of Social Security. Washington, DC: The Brookings Institution.

Brigham, Eugene F. and Joel F. Houston. 2007. Fundamentals of Financial Management.Eleventh Edition. Thomson South-Western. Chapter 11.

Brown, Jeffrey B., Julia Lynn Coronado, and Don Fullerton. 2009. "Is Social Security Part of the Social Safety Net?” In Tax Policy and the Economy, Volume 23, edited by Jeffrey R. Brown and James M. Poterba, 37-72. Chicago, IL: University of Chicago Press.

Brown, Jeffrey R., Jeffrey B. Liebman, and Joshua Pollet. 2002. "Estimating Life Tables that Reflect Socioeconomic Differences in Mortality." In The Distributional Effects of Social Security and Social Security Reform, edited by Martin Feldstein and Jeffrey B. Liebman, 447-457. Chicago, IL: University of Chicago Press.

Coronado, Julia Lynn, Don Fullerton, and Thomas Glass. 2000. "The Progressivity of Social Security.” Working Paper 7520. Cambridge, MA: National Bureau of Economic Research.

Cohen, Lee, C. Eugene Steuerle, and Adam Carasso. 2001. "Social Security Redistribution by Education, Race, and Income: How Much and Why." Research Report. Washington, DC: Tax Policy Center.

Department of the Treasury Internal Revenue Service. 2011. Instructions Form 1040.

Feenberg, Daniel and Elisabeth Coutts. 1993. "An Introduction to the TAXSIM Model." Journal of Policy Analysis and Management Vol. 12 no. 1.

Friedman, Milton. 1972. "Second Lecture." In Social Security: Universal or Selective? edited by Wilbur J. Cohen and Milton Friedman, 21-49. Washington, DC: American Enterprise Institute.

Goodman, Sarena and Jeffrey B. Liebman. 2008. "The Taxation of Social Security Benefits as an Approach to Means Testing." Paper presented at the Annual Conference of the Retirement Research Consortium.

Gustman, Alan L. and Thomas L. Steinmeier. 2001. "How Effective is Redistribution under the Social Security Benefit Formula?" The Journal of Public Economics 82(1): 1-28.

Hamermesh, Daniel S. and Albert Rees. 1993. The Economics of Work and Pay. New York, NY: Harper Collins College Publishers.

Harris, Amy and John Sabelhaus. 2005. "How Does Differential Mortality Affect Social Security Finances and Redistribution?” Working Paper 2005-5. Washington, DC: Congressional Budget Office.

Hinden, Stan. 2011. "Paying Taxes on Social Security.” AARP Bulletin, February 10.

Holt, Stephen D. 2006. "Keeping it in Context: Earned Income Tax Credit Compliance and Treatment of the Working Poor.” Connecticut Public Interest Law Journal 6(2): 183-203. 
Kapteyn, Arie, Pierre-Carl Michaud, James Smith and Arthur van Soest. 2006. "Effects of Attrition and Non-Response in the Health and Retirement Study." RAND Corporation, Working Paper WR-407.

Kiefer, Donald W. 1984. "Distributional Tax Redistribution Indexes.” National Tax Journal 37(4): 497-513.

Lerman, Robert I. and Shlomo Yitzhaki. 1995. "Changing Ranks and Inequality Impacts of Taxes and Transfers.” National Tax Journal 48(1): 45-59.

Liebman, Jeffrey B. 2002. "Redistribution in the Current U.S. Social Security System." In The Distributional Effects of Social Security and Social Security Reform, edited by Martin Feldstein and Jeffrey B. Liebman, 11-48. Chicago, IL: University of Chicago Press.

Musgrave, R.A., and Tun Thin. 1948. “Income Tax Progression 1929-1948.” Journal of Political Economy 56(6): 498-514.

Piketty, Thomas and Emmanuel Saez. 2007. "How Progressive is the U.S. Federal Tax System? A Historical and International Perspective." Journal of Economic Perspectives 21(1): 324.

Steven Ruggles, Matthew Sobek, Trent Alexander, Catherine A. Fitch, Ronald Goeken, Patricia Kelly Hall, Miriam King, and Chad Ronnander. Integrated Public Use Microdata Series: Version 4.0 [Machine-readable database]. Minneapolis, MN: Minnesota Population Center [producer and distributor], 2008.

Smith, Karen E., Eric Toder, and Howard Iams. 2001. "Lifetime Distributional Effects of Social Security Retirement Benefits.” Research Report. Washington, DC: Tax Policy Center.

U.S. Social Security Administration. 2011a. "Primary Insurance Amount." Available at: http://www.socialsecurity.gov/OACT/COLA/piaformula.html. 2011b. The Annual Report of the Board of Trustees of the Federal Old-Age and Survivors Insurance and Federal Disability Insurance Trust Funds. Washington, DC: U.S. Government Printing Office.

2011c. Annual Statistical Supplement to the Social Security Bulletin. Washington, DC: U.S. Government Printing Office. 
Figure 1. Revenue from Income Taxation of Social Security Benefits, in billions of 2010 dollars.

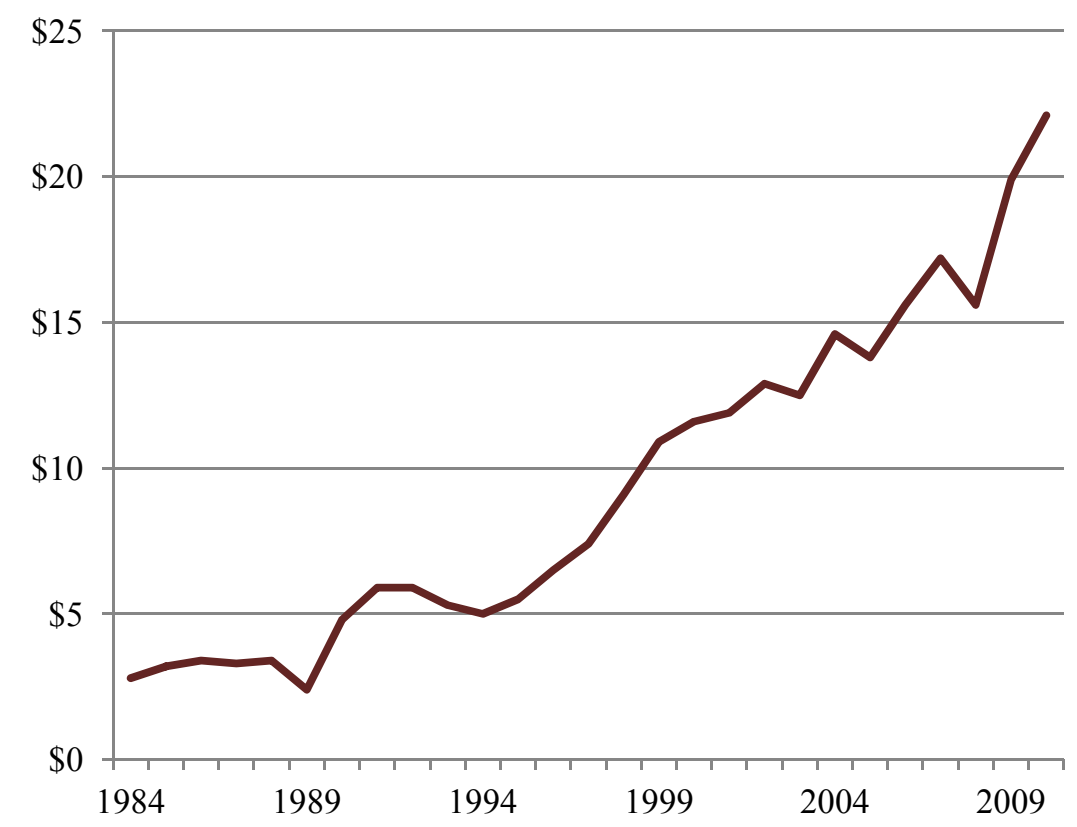

Source: 2011 Social Security Trustees Report, Table VI.B1.

Figure 2. Value of the EITC, by Income, Unmarried Filers, 2011.

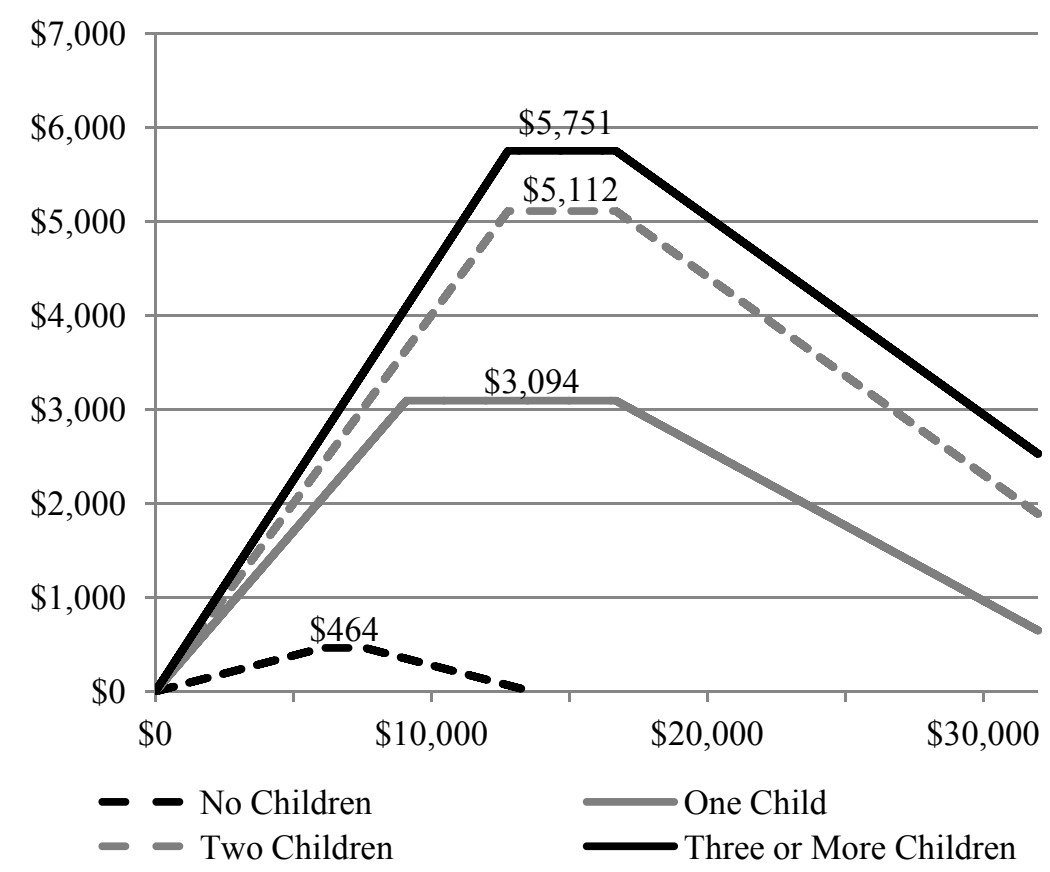

Source: Internal Revenue Service, Form 1040 Instructions. 
Figure 3: Effective Marginal Tax Rates for a Family of Four, 2011.

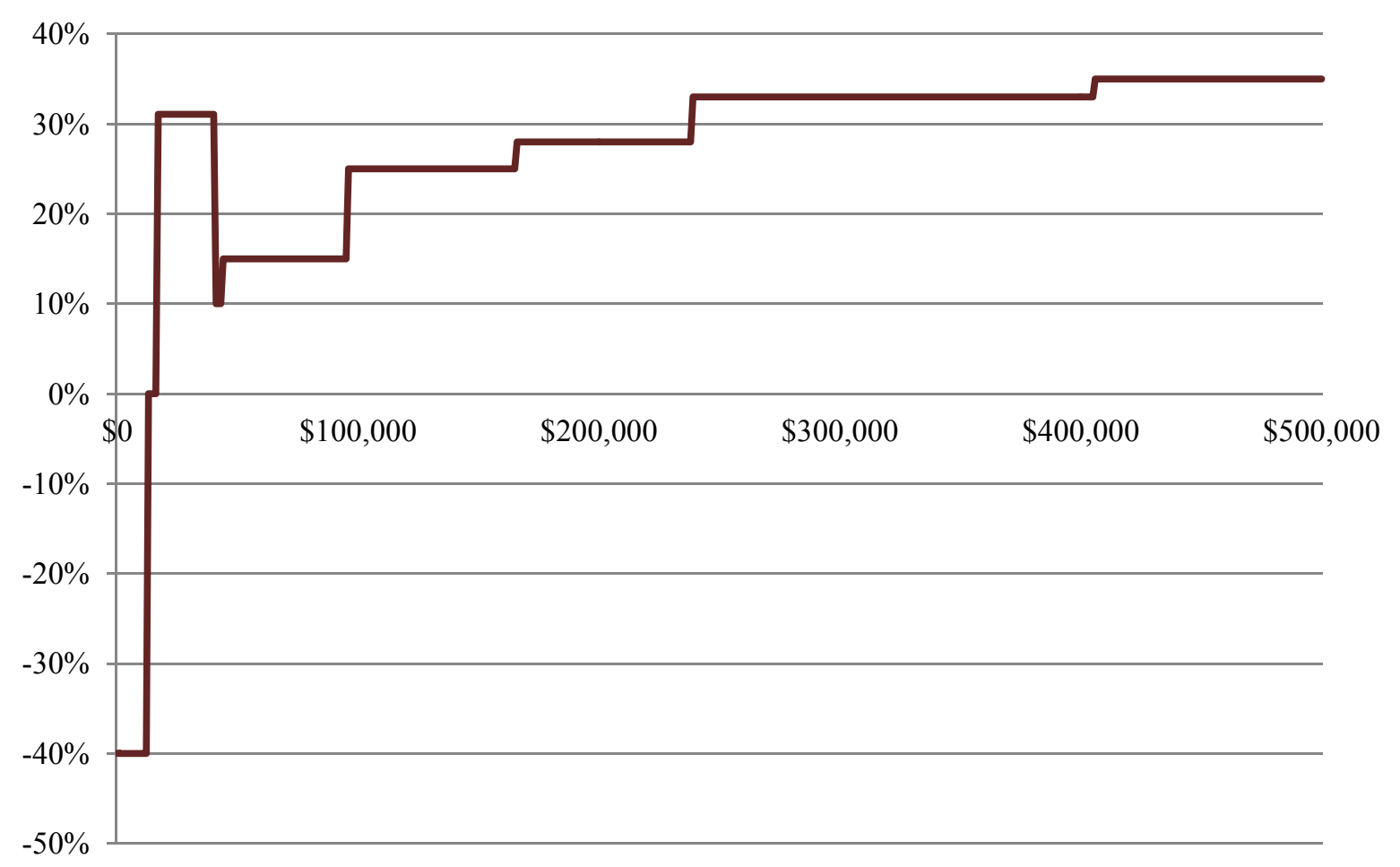

Source: Authors' calculations using the Internal Revenue Service, Form 1040 Instructions and EITC parameters. 
Figure 4. Workforce Participation Rates of Women Aged 35-44, by Marital Status, 1900-2009

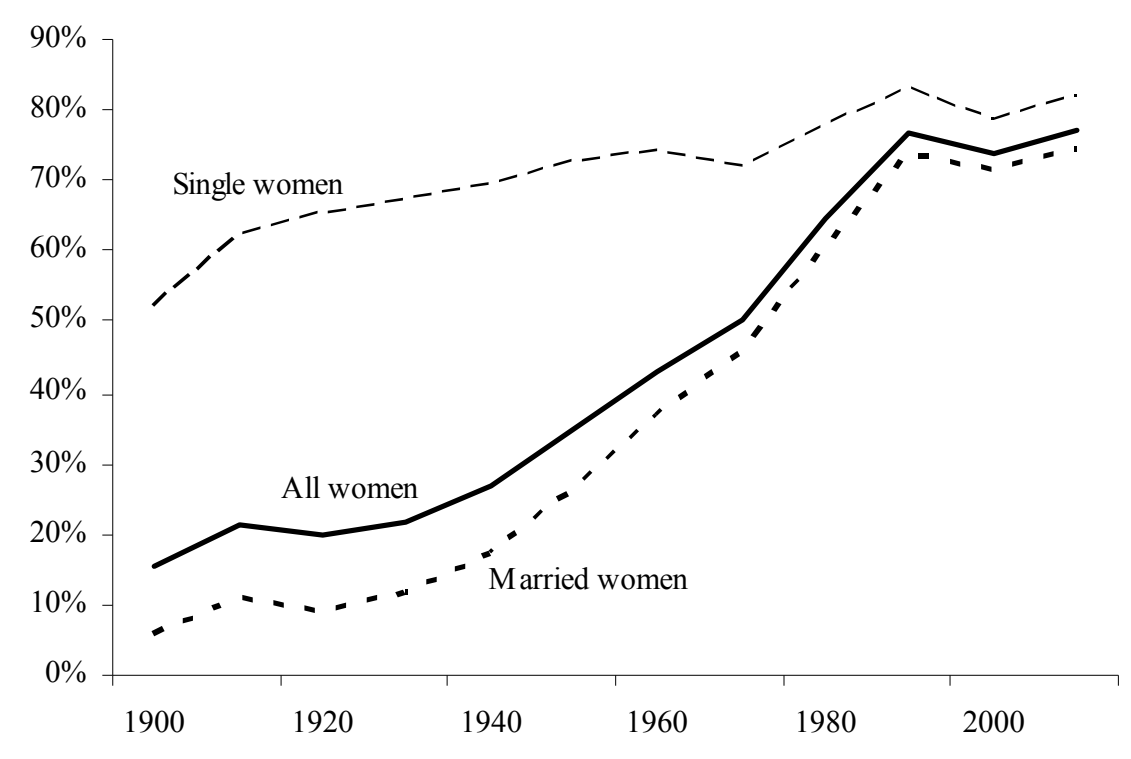

Source: Steven Ruggles, Matthew Sobek, Trent Alexander, Catherine A. Fitch, Ronald Goeken, Patricia Kelly Hall, Miriam King, and Chad Ronnander. Integrated Public Use Microdata Series: Version 4.0 [Machine-readable database]. Minneapolis, MN: Minnesota Population Center [producer and distributor], 2008. 
Table 1: Descriptive Statistics, by Annual Indexed AIME and Cohort

\begin{tabular}{|c|c|c|c|c|c|c|}
\hline \multirow[b]{2}{*}{$\begin{array}{l}\text { Individual } \\
\text { annualized } \\
\text { AIME decile }\end{array}$} & \multicolumn{3}{|c|}{ Men } & \multicolumn{3}{|c|}{ Women } \\
\hline & $\begin{array}{l}\% \text { of } \\
\text { total }\end{array}$ & $\begin{array}{l}\text { Average } \\
\text { covered } \\
\text { quarters }\end{array}$ & $\begin{array}{c}\text { Average } \\
\text { household AIME } \\
\text { (thousands) }\end{array}$ & $\begin{array}{l}\% \text { of } \\
\text { total }\end{array}$ & $\begin{array}{l}\text { Average } \\
\text { covered } \\
\text { quarters }\end{array}$ & $\begin{array}{c}\text { Average } \\
\text { household AIME } \\
\text { (thousands) }\end{array}$ \\
\hline \multicolumn{7}{|l|}{ HRS Cohort } \\
\hline 1 & 3 & 23 & $\$ 6$ & 19 & 19 & $\$ 21$ \\
\hline 2 & 3 & 66 & 8 & 14 & 65 & 23 \\
\hline 3 & 5 & 82 & 11 & 15 & 90 & 28 \\
\hline 4 & 6 & 107 & 16 & 13 & 114 & 31 \\
\hline 5 & 7 & 132 & 21 & 12 & 132 & 34 \\
\hline 6 & 10 & 147 & 25 & 10 & 144 & 38 \\
\hline 7 & 13 & 162 & 29 & 7 & 153 & 41 \\
\hline 8 & 16 & 164 & 35 & 5 & 155 & 46 \\
\hline 9 & 18 & 166 & 41 & 3 & 159 & 54 \\
\hline 10 & 19 & 172 & 48 & 2 & 163 & 59 \\
\hline Total & 100 & 143 & 31 & 100 & 94 & 31 \\
\hline \multicolumn{7}{|l|}{ WB Cohort } \\
\hline 1 & 6 & 22 & $\$ 8$ & 15 & 19 & $\$ 20$ \\
\hline 2 & 4 & 70 & 11 & 18 & 80 & 26 \\
\hline 3 & 7 & 105 & 17 & 14 & 115 & 31 \\
\hline 4 & 8 & 131 & 22 & 13 & 138 & 33 \\
\hline 5 & 11 & 156 & 28 & 9 & 149 & 35 \\
\hline 6 & 11 & 165 & 32 & 9 & 157 & 43 \\
\hline 7 & 12 & 167 & 38 & 8 & 156 & 50 \\
\hline 8 & 13 & 170 & 43 & 6 & 162 & 51 \\
\hline 9 & 14 & 171 & 48 & 5 & 158 & 49 \\
\hline 10 & 15 & 174 & 58 & 3 & 167 & 70 \\
\hline Total & 100 & 145 & 36 & 100 & 110 & 35 \\
\hline \multicolumn{7}{|l|}{ EBB Cohort } \\
\hline 1 & 6 & 32 & $\$ 8$ & 15 & 29 & $\$ 17$ \\
\hline 2 & 6 & 91 & 11 & 15 & 95 & 22 \\
\hline 3 & 7 & 116 & 16 & 14 & 126 & 28 \\
\hline 4 & 8 & 144 & 20 & 12 & 147 & 32 \\
\hline 5 & 9 & 160 & 24 & 12 & 160 & 35 \\
\hline 6 & 11 & 171 & 30 & 9 & 161 & 39 \\
\hline 7 & 11 & 167 & 36 & 8 & 161 & 44 \\
\hline 8 & 13 & 174 & 42 & 6 & 168 & 48 \\
\hline 9 & 13 & 175 & 49 & 6 & 172 & 56 \\
\hline 10 & 15 & 177 & 57 & 3 & 168 & 64 \\
\hline Total & 100 & 147 & 34 & 100 & 120 & 33 \\
\hline
\end{tabular}

Source: Authors' calculations using the Health and Retirement Study (HRS). 
Table 2: HRS Baseline Measure of Percent Redistributed by Decile of OASI program, Individuals and Families

\begin{tabular}{|c|c|c|c|c|c|c|c|c|c|c|c|}
\hline \multirow{2}{*}{ Unit } & \multicolumn{10}{|c|}{ AIME Deciles } & \multirow{2}{*}{ Overall } \\
\hline & 1 & 2 & 3 & 4 & 5 & 6 & 7 & 8 & 9 & 10 & \\
\hline
\end{tabular}

Individual Benefits, Individual AIME

\begin{tabular}{|l|c|c|c|c|c|c|c|c|c|c|c|}
\hline $\begin{array}{l}\text { Taxes Paid } \\
\text { (thousands) }\end{array}$ & $\$ 5$ & 13 & 26 & 43 & 62 & 85 & 108 & 131 & 156 & 187 & 82 \\
\hline $\begin{array}{l}\text { Benefits Received } \\
\text { (thousands) }\end{array}$ & $\$ 0$ & 29 & 48 & 59 & 72 & 84 & 94 & 106 & 115 & 124 & 73 \\
\hline Percent Redistributed & $-0.73 \%$ & 1.99 & 3.38 & 2.81 & 2.23 & 1.24 & -0.27 & -1.44 & -3.27 & -5.95 & $11.66 \%$ \\
\hline
\end{tabular}

Family Benefits, Individual AIME

\begin{tabular}{|c|c|c|c|c|c|c|c|c|c|c|c|}
\hline $\begin{array}{l}\text { Taxes Paid } \\
\text { (thousands) }\end{array}$ & $\$ 5$ & 13 & 26 & 43 & 62 & 85 & 108 & 131 & 156 & 187 & 82 \\
\hline $\begin{array}{l}\text { Benefits Received } \\
\text { (thousands) }\end{array}$ & $\$ 53$ & 60 & 69 & 71 & 80 & 89 & 97 & 107 & 116 & 124 & 86 \\
\hline Percent Redistributed & $6.32 \%$ & 4.52 & 4.70 & 2.96 & 1.65 & -0.04 & -2.09 & -3.67 & -5.74 & -8.62 & $20.14 \%$ \\
\hline \multicolumn{12}{|c|}{ Family Benefits, Family AIME } \\
\hline $\begin{array}{l}\text { Taxes Paid } \\
\text { (thousands) }\end{array}$ & $\$ 24$ & 66 & 99 & 124 & 148 & 166 & 185 & 207 & 233 & 292 & 154 \\
\hline $\begin{array}{l}\text { Benefits Received } \\
\text { (thousands) }\end{array}$ & $\$ 45$ & 102 & 133 & 156 & 173 & 183 & 196 & 205 & 221 & 253 & 167 \\
\hline Percent Redistributed & $1.17 \%$ & 1.82 & 1.52 & 1.30 & 0.85 & 0.22 & -0.21 & -1.10 & -1.84 & -3.73 & $6.88 \%$ \\
\hline
\end{tabular}

Source: Authors' calculations using the Health and Retirement Study (HRS) on the HRS cohort (1931-1941). 
Table 3. HRS Cohort Baseline Measure of Effective Progression of OASI Program, Individuals and Families

\begin{tabular}{|l|c|c|c|}
\hline \multirow{2}{*}{ Unit } & \multicolumn{2}{|c|}{ Gini Coefficient } & \multirow{2}{*}{ Effective Progression } \\
\cline { 2 - 4 } & Before Social Security & After Social Security & \\
\hline Individual & 0.5588 & 0.5539 & 1.0110 \\
\hline Family & 0.3964 & 0.3920 & 1.0073 \\
\hline
\end{tabular}

Source: Authors' calculations using the Health and Retirement Study (HRS) on the HRS cohort (1931-1941). 
Table 4. HRS Measure of Redistribution by Decile of OASI Program with Personal Income Tax Provisions, Individuals and Families

\begin{tabular}{|c|c|c|c|c|c|c|c|c|c|c|c|}
\hline & \multicolumn{7}{|c|}{ AIME Deciles } & \multicolumn{2}{c|}{$\begin{array}{c}\% \\
\text { redistributed }\end{array}$} \\
\cline { 2 - 10 } \\
\cline { 2 - 10 }
\end{tabular}

\section{Individual}

\begin{tabular}{|l|c|l|l|l|l|l|l|l|l|l|l|}
\hline Baseline & $-0.73 \%$ & 1.99 & 3.38 & 2.81 & 2.23 & 1.24 & -0.27 & -1.44 & -3.27 & -5.95 & 11.66 \\
\hline $\begin{array}{l}\text { Excl. of } \\
\text { emp. tax }\end{array}$ & $-0.77 \%$ & 1.91 & 3.23 & 2.60 & 1.98 & 0.98 & -0.47 & -1.43 & -2.89 & -5.14 & 10.70 \\
\hline EITC & $-0.76 \%$ & 1.94 & 3.25 & 2.61 & 1.98 & 0.98 & -0.48 & -1.44 & -2.91 & -5.16 & 10.75 \\
\hline Benefits & $-0.76 \%$ & 2.03 & 3.45 & 2.81 & 2.30 & 1.28 & -0.31 & -1.30 & -3.29 & -6.21 & 11.87 \\
\hline
\end{tabular}

Family

\begin{tabular}{|l|c|c|c|c|c|c|c|c|c|c|c|}
\hline Baseline & $1.17 \%$ & 1.82 & 1.52 & 1.30 & 0.85 & 0.22 & -0.21 & -1.10 & -1.84 & -3.73 & 6.88 \\
\hline $\begin{array}{l}\text { Excl. of } \\
\text { emp. tax }\end{array}$ & $1.05 \%$ & 1.58 & 1.26 & 1.06 & 0.69 & 0.13 & -0.17 & -0.95 & -1.55 & -3.11 & 5.78 \\
\hline EITC & $1.07 \%$ & 1.59 & 1.27 & 1.07 & 0.69 & 0.13 & -0.18 & -0.96 & -1.56 & -3.13 & 5.82 \\
\hline Benefits & $1.12 \%$ & 1.75 & 1.45 & 1.29 & 0.92 & 0.30 & -0.14 & -0.95 & -1.79 & -3.96 & 6.83 \\
\hline
\end{tabular}

Source: Authors' calculations using the Health and Retirement Study (HRS). 
Table 5. Measures of Redistribution by Decile of OASI Program with Personal Income Tax Provisions, HRS to WB Cohort

\begin{tabular}{|c|c|c|c|c|c|c|c|c|c|c|c|}
\hline \multirow{2}{*}{ Unit } & \multicolumn{10}{|c|}{ AIME Deciles } & \multirow{2}{*}{ Overal } \\
\hline & 1 & 2 & 3 & 4 & 5 & 6 & 7 & 8 & 9 & 10 & \\
\hline \multicolumn{12}{|c|}{ Base Case: Respondents born 1936-1941 } \\
\hline $\begin{array}{l}\text { Taxes Paid } \\
\text { (thousands) }\end{array}$ & $\$ 5$ & 13 & 28 & 45 & 64 & 87 & 112 & 139 & 165 & 197 & 85 \\
\hline $\begin{array}{l}\text { Benefits } \\
\text { Received } \\
\text { (thousands) }\end{array}$ & $\$ 0$ & 29 & 49 & 59 & 71 & 83 & 95 & 104 & 115 & 126 & 73 \\
\hline $\begin{array}{l}\text { Percent } \\
\text { Redistributed }\end{array}$ & $-0.67 \%$ & 2.17 & 3.37 & 2.89 & 2.29 & 1.22 & -0.07 & -1.93 & -3.57 & -5.70 & 11.94 \\
\hline \multicolumn{12}{|c|}{ Step 1: Moving earnings forward with AWI } \\
\hline Taxes Paid & $\$ 7$ & 18 & 37 & 60 & 86 & 116 & 152 & 190 & 224 & 261 & 115 \\
\hline $\begin{array}{l}\text { Benefits } \\
\text { Received }\end{array}$ & $\$ 0$ & 27 & 44 & 54 & 64 & 74 & 84 & 92 & 101 & 109 & 65 \\
\hline $\begin{array}{l}\text { Percent } \\
\text { Redistributed }\end{array}$ & $-0.66 \%$ & 2.31 & 3.60 & 3.09 & 2.51 & 1.30 & -0.20 & -2.33 & -3.86 & -5.77 & 12.81 \\
\hline \multicolumn{12}{|c|}{ Step 2: Mortality } \\
\hline Taxes Paid & $\$ 7$ & 18 & 38 & 61 & 88 & 120 & 156 & 196 & 231 & 269 & 118 \\
\hline $\begin{array}{l}\text { Benefits } \\
\text { Received }\end{array}$ & $\$ 0$ & 36 & 59 & 72 & 87 & 100 & 115 & 126 & 138 & 149 & 88 \\
\hline $\begin{array}{l}\text { Percent } \\
\text { Redistributed }\end{array}$ & $-0.65 \%$ & 2.26 & 3.50 & 3.05 & 2.47 & 1.31 & -0.11 & -2.22 & -3.82 & -5.78 & 12.59 \\
\hline \multicolumn{12}{|c|}{ Step 3: FICA tax rate \& FRA increases } \\
\hline Taxes Paid & $\$ 8$ & 21 & 43 & 68 & 97 & 131 & 172 & 215 & 252 & 291 & 129 \\
\hline $\begin{array}{l}\text { Benefits } \\
\text { Received }\end{array}$ & $\$ 0$ & 34 & 57 & 69 & 84 & 96 & 110 & 121 & 132 & 143 & 84 \\
\hline $\begin{array}{l}\text { Percent } \\
\text { Redistributed }\end{array}$ & $-0.70 \%$ & 2.22 & 3.44 & 3.01 & 2.43 & 1.30 & -0.18 & -2.29 & -3.76 & -5.46 & 12.39 \\
\hline \multicolumn{12}{|c|}{ Step 4: Interest rate } \\
\hline Taxes Paid & $\$ 6$ & 14 & 28 & 44 & 63 & 84 & 110 & 137 & 160 & 186 & 83 \\
\hline $\begin{array}{l}\text { Benefits } \\
\text { Received }\end{array}$ & $\$ 0$ & 26 & 43 & 52 & 63 & 72 & 83 & 91 & 100 & 108 & 63 \\
\hline $\begin{array}{l}\text { Percent } \\
\text { Redistributed }\end{array}$ & $-0.76 \%$ & 2.16 & 3.35 & 2.94 & 2.36 & 1.27 & -0.19 & -2.15 & -3.60 & -5.38 & 12.08 \\
\hline \multicolumn{12}{|c|}{ Base Case: WB cohort } \\
\hline Taxes Paid & $\$ 6$ & 19 & 40 & 61 & 86 & 110 & 134 & 155 & 180 & 209 & 100 \\
\hline $\begin{array}{l}\text { Benefits } \\
\text { Received }\end{array}$ & $\$ 0$ & 31 & 48 & 60 & 70 & 86 & 96 & 100 & 105 & 115 & 71 \\
\hline $\begin{array}{l}\text { Percent } \\
\text { Redistributed }\end{array}$ & $-0.52 \%$ & 2.55 & 2.80 & 2.31 & 1.24 & 1.00 & 0.15 & -1.52 & -3.25 & -4.76 & 10.05 \\
\hline
\end{tabular}

Source: Authors' calculations using the Health and Retirement Study (HRS). 
Table 6. Measures of Redistribution of OASI Program with Personal Income Tax Provisions, Individuals and Families

\begin{tabular}{|c|c|c|c|c|c|c|c|c|c|c|c|}
\hline \multirow{2}{*}{ Provision } & \multicolumn{10}{|c|}{ AIME Deciles } & $\begin{array}{c}\% \\
\text { redistribute } \\
\mathrm{nyyyyyyyyy}\end{array}$ \\
\cline { 2 - 11 } & 1 & 2 & 3 & 4 & 5 & 6 & 7 & 8 & 9 & 10 & $\mathrm{~d}$ \\
\hline
\end{tabular}

\section{Individual}

\begin{tabular}{|l|c|c|c|c|c|c|c|c|c|c|c|}
\hline $\begin{array}{l}\text { Baseline } \\
\text { HRS }\end{array}$ & $-0.73 \%$ & 1.99 & 3.38 & 2.81 & 2.23 & 1.24 & -0.27 & -1.44 & -3.27 & -5.95 & 11.66 \\
\hline $\begin{array}{l}\text { HRS with } \\
\text { Taxes }\end{array}$ & $-0.76 \%$ & 2.03 & 3.45 & 2.81 & 2.30 & 1.28 & -0.31 & -1.30 & -3.29 & -6.21 & 11.87 \\
\hline $\begin{array}{l}\text { Baseline } \\
\text { WB }\end{array}$ & $-0.52 \%$ & 2.55 & 2.80 & 2.31 & 1.24 & 1.00 & 0.15 & -1.52 & -3.25 & -4.76 & 10.05 \\
\hline $\begin{array}{l}\text { WB with } \\
\text { Taxes }\end{array}$ & $-0.55 \%$ & 2.65 & 2.90 & 2.35 & 1.25 & 1.10 & 0.26 & -1.59 & -3.49 & -4.88 & 10.50 \\
\hline $\begin{array}{l}\text { Baseline } \\
\text { EBB }\end{array}$ & $-0.27 \%$ & 2.68 & 2.74 & 2.19 & 1.70 & 0.84 & 0.30 & -1.76 & -3.23 & -5.18 & 10.44 \\
\hline $\begin{array}{l}\text { EBB with } \\
\text { Taxes }\end{array}$ & $-0.26 \%$ & 2.80 & 2.81 & 2.23 & 1.73 & 0.78 & 0.34 & -1.57 & -3.23 & -5.62 & 10.68 \\
\hline
\end{tabular}

Family

\begin{tabular}{|l|c|c|c|c|c|c|c|c|c|c|c|}
\hline $\begin{array}{l}\text { Baseline } \\
\text { HRS }\end{array}$ & $1.17 \%$ & 1.82 & 1.52 & 1.30 & 0.85 & 0.22 & -0.21 & -1.10 & -1.84 & -3.73 & 6.88 \\
\hline $\begin{array}{l}\text { HRS with } \\
\text { Taxes }\end{array}$ & $1.12 \%$ & 1.75 & 1.45 & 1.29 & 0.92 & 0.30 & -0.14 & -0.95 & -1.79 & -3.96 & 6.83 \\
\hline $\begin{array}{l}\text { Baseline } \\
\text { WB }\end{array}$ & $0.80 \%$ & 1.59 & 1.51 & 1.23 & 0.93 & 0.47 & 0.02 & -0.69 & -1.88 & -3.97 & 6.55 \\
\hline $\begin{array}{l}\text { WB with } \\
\text { Taxes }\end{array}$ & $0.81 \%$ & 1.60 & 1.49 & 1.26 & 1.06 & 0.32 & 0.09 & -0.65 & -1.94 & -4.04 & 6.63 \\
\hline $\begin{array}{l}\text { Baseline } \\
\text { EBB }\end{array}$ & $0.79 \%$ & 1.67 & 1.71 & 1.17 & 1.19 & 0.51 & -0.44 & -0.70 & -1.41 & -4.48 & 7.03 \\
\hline $\begin{array}{l}\text { EBB with } \\
\text { Taxes }\end{array}$ & $0.83 \%$ & 1.69 & 1.71 & 1.16 & 1.25 & 0.53 & -0.46 & -0.67 & -1.45 & -4.60 & 7.18 \\
\hline
\end{tabular}

Source: Authors' calculations using the Health and Retirement Study (HRS). 
Table 7. Measures of Effective Progression of OASI Program with Personal Income Tax Provisions, Individuals and Families

\begin{tabular}{|l|c|c|c|c|}
\hline \multirow{3}{*}{ Unit } & \multicolumn{2}{|c|}{ Gini Coefficient } & \multirow{2}{\text{Effective}}{$\begin{array}{c}\text { Difference in } \\
\text { Progression }\end{array}$} & $\begin{array}{c}\text { EP due to } \\
\text { Taxation }\end{array}$ \\
\cline { 2 - 3 } & $\begin{array}{c}\text { Before Social } \\
\text { Security }\end{array}$ & $\begin{array}{c}\text { After Social } \\
\text { Security }\end{array}$ & \\
\hline
\end{tabular}

\section{Individual}

\begin{tabular}{|l|c|c|c|c|}
\hline Baseline HRS & 0.5588 & 0.5539 & 1.0110 & \\
\hline HRS with Taxes & 0.5588 & 0.5536 & 1.0117 & 0.0007 \\
\hline Baseline WB & 0.5556 & 0.5538 & 1.0041 & 0.0012 \\
\hline WB with Taxes & 0.5556 & 0.5533 & 1.0053 & \\
\hline Baseline EBB & 0.5708 & 0.5686 & 1.0050 & 0.0014 \\
\hline EBB with Taxes & 0.5708 & 0.5680 & 1.0064 & \\
\hline
\end{tabular}

\section{Family}

\begin{tabular}{|l|c|c|c|c|}
\hline Baseline HRS & 0.3964 & 0.3920 & 1.0073 & \\
\hline HRS with Taxes & 0.3964 & 0.3919 & 1.0075 & 0.0002 \\
\hline Baseline WB & 0.4633 & 0.4610 & 1.0043 & \\
\hline WB with Taxes & 0.4633 & 0.4604 & 1.0053 & 0.0010 \\
\hline Baseline EBB & 0.5032 & 0.5003 & 1.0058 & 0.0012 \\
\hline EBB with Taxes & 0.5032 & 0.4997 & 1.0070 & \\
\hline
\end{tabular}

Source: Authors' calculations using the Health and Retirement Study (HRS). 


\section{RECENT WORKING PAPERS FROM THE CENTER FOR RETIREMENT RESEARCH AT BOSTON COLLEGE}

The Pension Protection Act of 2006 and Diversification of Employer Stock in Defined Contribution Plans

Gary V. Engelhardt, November 2011

Prescription Drug Insurance Coverage, Drug Utilization, and Cost-Related NonAdherence: Evidence from the Medicare Part D Expansion

Gary V. Engelhardt, November 2011

Social Security on Auto-Pilot: International Experience with Automatic Stabilizer Mechanisms

Barry Bosworth and R. Kent Weaver, November 2011

The Impact of Unemployment Insurance Extensions on Disability Insurance Application and Allowance Rates

Matthew S. Rutledge, October 2011

Do Couples Self-Insure? The Effect of Informal Care on a Couple's Labor Supply

Norma B. Coe, Meghan Skira, and Courtney Harold Van Houtven, October 2011

How Prepared are State and Local Workers for Retirement?

Alicia H. Munnell, Jean-Pierre Aubry, Josh Hurwitz, and Laura Quinby, October 2011

Social Security Reform and Male Labor Force Participation Around the World Jocelyn E. Finlay and Günther Fink, September 2011

Corporate Pension Plan Investments in Alternative Assets: Determinants and Consequences

Divya Anantharaman, August 2011

Social Security Reform and Male Labor Force Participation Around the World Jocelyn E. Finlay and Günther Fink, June 2011

An In-Depth Look into Intergenerational Flows

Oksana Leukhina and Marika Santoro, May 2011

Who Retires Early?

Henry J. Aaron and Jean Marie Callan, May 2011

The Potential Impact of the Great Recession on Future Retirement Incomes Barbara A. Butrica, Richard W. Johnson, and Karen E. Smith, May 2011

All working papers are available on the Center for Retirement Research website (http://crr.bc.edu) and can be requested by e-mail (crr@bc.edu) or phone (617-552-1762). 